Vol 3, No. 1, Agustus 2018: 227 -234, DOI: https://doi.org/10.34007/jehss.v3i1.280

\title{
Kebijakan Pemerintah Provinsi Sumatera Utara untuk Usaha Mikro Kecil dan Menengah dalam Masyarakat Ekonomi ASEAN
}

\section{North Sumatra Provincial Government Policies for Micro, Small and Medium Enterprises in the ASEAN Economic Community}

\author{
Evi Yunita Kurniaty* \\ Program Studi Ilmu Pemerintahan, Fakultas Ilmu Sosial dan Ilmu Politik \\ Universitas Medan Area, Indonesia
}

Diterima: 04 Agustus 2020; Disetujui: 08 Agustus 2020; Dipublish: 09 Agustus 2020

*Coresponding Email: evithalib@gmail.com

\section{Abstrak}

Dalam penelitian ini difokuskan untuk menganalisa kebijakan ekonomi politik Pemerintah Provinsi Sumatera Utara dalam Masyarakat Ekonomi Asean (MEA) terhadap Usaha Mikro Kecil dan Menengah (UMKM). Penelitian ini dilakukan dengan tujuan untuk melihat validitas idologi liberalisme terhadap kebijakan ekonomi politik Pemerintah Provinsi Sumatera Utara dalam MEA bagi UMKM yang ada di Sumatera Utara. Metode yang digunakan dalam penelitian ini adalah deskriptif kualitatif yang lebih menekankan pada kebijakan Pemerintah Provinsi Sumatera Utara dalam MEA, peluang serta hambatan yang muncul bagi UMKM. Hasil penelitian ini diharapkan menjadi acuan dan solusi untuk Pemerintah Provinsi Sumatera Utara dalam membuat kebiajakan untuk Usaha Mikro Kecil dan Menengah dalam menjalankan Masyarakat Ekonomi Asean. Kebijakan politik yang dihasilkan selanjutnya merupakan kebijakan yang dapat memanfaatkan peluang dan menjawab tantangan yang ada dalam MEA. Dengan kebijakan politik pemerintah yang tepat sasaran akan mewujudkan tujuan pembangunan bersama. Kata Kunci: Kebijakan Pemerintahan, Masyarakat Ekonomi Asean, Usaha Mikro Kecil dan Menengah.

\section{Abstract}

$n$ this study, it is focused on analyzing the political economy policy of the North Sumatra Provincial Government in the Asean Economic Community (AEC) towards Micro, Small and Medium Enterprises (MSMEs). This research was conducted with the aim to see the validity of the ideology of liberalism on the political economy policy of the North Sumatra Provincial Government in the AEC for MSMEs in North Sumatra. The method used in this research is descriptive qualitative which emphasizes the policy of the Government of North Sumatra Province in the AEC, opportunities and obstacles that arise for MSMEs. The results of this study are expected to be a reference and solution for the Government of the Province of North Sumatra in making policy for Micro Small and Medium Enterprises in running the Asean Economic Community. The resulting political policy is a policy that can take advantage of opportunities and answer the challenges that exist in the AEC. With government political policies that are right on target, they will realize shared development goals.

Keywords: Government Policy, Asean Economic Community, Micro Small and Medium Enterprises.

How to Cite: Kurniaty, E.Y., (2020), Kebijakan Pemerintah Provinsi Sumatera Utara untuk Usaha Mikro Kecil dan Menengah dalam Masyarakat Ekonomi ASEAN, Journal of Education, Humaniora and Social Sciences (JEHSS), 3(1): $227-234$ 


\section{PENDAHULUAN}

Pada akhir tahun 2015, tepatnya tanggal 31 Desember 2015, kesepakatan perdagangan bebas ASEAN atau yang lebih dikenal Masyarakat Ekonomi ASEAN sudah mulai diberlakukan. Sebagian berharap MEA akan memberikan dampak positif terhadap ekonomi Indonesia. Namun, kebanyakan kalangan justru menganggap MEA ini sebagai ancaman karena daya saing beberapa sektor industri kita masih kalah dibandingkan dengan negara-negara ASEAN.

Daya saing Indonesia dinilai masih lemah terutama masalah pangan. Dengan pemberlakuan MEA, Indonesia diperkirakan masih akan cenderung menjadi target pasar dari beberapa negara ASEAN yang dinilai lebih siap dari Indonesia, seperti Singapura, Malaysia dan Thailand. Apalagi sektor pangan di Indonesia saat ini masih selalu berorientasi pada pasokan, bukan mengendalikan permintaan. Ditambah lagi dengan kepentingan sekelompok orang yang mengambil keuntungan dari impor atau mafia impor, yang telah menghancurkan semua potensi yang ada.

Tujuan penelitian ini untuk melihat penerapan teori liberalisme dalam kerjasama regional Masyarakat Ekonomi Asean (MEA). Kebijakan-kebijakan politik Pemerintahan Provinsi Sumatera Utara dalam menghadapi MEA. Seharusnya kebijakan yang dihasilkan harus memanfaatkan peluang yang ada dan menjawab segala tantangan dan hambatan yang terjadi diterapkannya MEA. Kebijakan tersebut seperti sosialisasi besar-besaran atas kehadiran MEA ini. Pemerintah, penguasaha dan masyarakat atau dari kalangan atas sampai kalangan bawah harus mengenal MEA itu seperti apa. Sehingga semua pihak dapat mengambil bagian dalam MEA. Harus sama-sama mampu memanfaatkan peluang dan mampu menjawab hambatan yang terjadi. Selain sosialisasi kebijakan tersebut harus dapat memberdayakan usaha mikro, kecil dan menegah (UMKM).

Kesiapan Indonesia dalam hal ini Provinsi Sumatera Utara dalam dalam Pelaksanaan Masyarakat Ekonomi ASEAN (MEA) masih terkendala pada lemahnya berbagai bidang, antara lain, kesiapan Sumberdaya Manusia (khususnya UMKM), sarana dan prasarana produksi, modal usaha, infrastruktur wilayah, serta daya saing produk UMKM. Pemberlakuan kebijakan MEA itu dapat menjadi berkah ataupun sebaliknya malah mampu sebagai ancaman. Ini sangat bergantung pada kesiapan pemerintah baik pusat maupun daerah dan masyarakat khususnya UMKM dalam menghadapinya (Cahyani, dkk., 2019; Arini, dkk., 2018; Sulistia, dkk., 2019) Namun, hingga kini Indonesia masih menghadapi masalah-masalah mendasar, khususnya dalam bidang ekonomi, politik, sosial budaya serta stabilitas keamanan.

Pemerintah membuat sejumlah kebijakan strategis dan teknis, baik yang bersifat sektoral maupun lintas sektoral. Kebijakan strategis lintas sektoral antara lain penerbitan Master plan Percepatan Pembangunan Ekonomi Indonesia (MP3EI), pengembangan Sistem Logistik Nasional (Sislognas), kebijakan Hilirisasi sektor industri nasional, kebijakan ketahanan pangan, Sistem Kompetensi Kerja Nasional Indonesia, mendirikan ASEAN Center serta Pusat Studi ASEAN di beberapa universitas dan sebagainya.

Dukungan teknis juga diberikan pemerintah antara lain pembukaan Indonesia National Single Window (INSW) sebagai sarana untuk memfasilitasi para pelaku usaha. Kemudian, aplikasi online diseluruh kantor/instansi penerbit Surat keterangan Asal (SKA) untuk lebih mempermudah eksportir nasional, penerapan Standard Nasional Indonesia (SNI) untuk peningkatan mutu produk nasional sekaligus memastikan produk impor memenuhui aturan yang berlaku di dalam negeri.

Pemerintah dalam membangun koordinasi antara kementerian/lembaga termasuk para pelaku usaha, mengeluarkan berbagai kebijakan yang terutang dalam intrumen Instruksi Presiden (Inpres) No.5/2008 tentang Fokus Program Ekonomi dan Inpres No. 11/2011 tentang Pelaksanaan Komitmen Cetak Biru Masyarakat Ekonomi ASEAN. Inpres tersebut diperuntukkan sebagai pedoman bagi aparat baik pusat maupun daerah.

\section{METODE PENELITIAN}

Para peneliti kualittaif teguh pada posisi yang emis (berupaya menemukan fakta"apa adanya" bukan "apa yang seharusnya". (Denzin dan Lincoln, 2000). Kekhasan dari metode kualitatif ini peneliti diberikan otonomi sebesar-besarnya mengembangkan proses penelitian 
(Bungin, 2007). Menggunakan metode ini diharapkan persiapan dan kendala yang dihadapi Indonesia dalam Masyarakat Ekonomi Asean bisa dianalisis secara tajam dan mendalam.

Penelitian menggunakan metode penelitian kualitatif, yang secara teoritis format penelitian kualitatif berbeda dengan format penelitian kuantitatif. Penelitian kualitatif adalah suatu pendekatan yang juga disebut pendekatan investigasi karena biasanya peneliti mengumpulkan data dengan cara bertatap muka langsung dan berinteraksi dengan orang-orang di tempat penelitian (McMillan \& Schumacher, 2003).

Selanjutnya penelitian kualitatif menurut Moleong (2007) adalah penelitian yang bermaksud untuk memahami fenomena tentang apa yang dialami oleh subjek penelitian misalnya perilaku, persepsi, motivasi, tindakan, dan lain-lain., secara holistik, dan dengan cara deskripsi dalam bentuk kata kata dan bahasa, pada suatu konteks khusus yang alamiah dan dengan memanfaatkan berbagai metode alamiah.

Penelitian kualitatif tidak terikat dengan disiplin tunggal manapun (Denzin dan Lincoln, 2009). Dalam konteks penelitian ini sejalan dengan masalah penelitian yang menggabungkan disiplin ilmu politik dan kajian ekonomi politik. Metode kualitatif yang digunakan disini berusaha membangun konsep perdagangan bebas yang bersumber dari pemikiran liberalisme. Disini banyak dibicarakan teori liberalisme untuk menelaah dijalankannya Masyarakat Ekonomi Asean (MEA) di Sumatera Utara. Inilah argument bahwa dalam penelitian ini paradigm dan metode penelitian kualitatif menjadi relevan.

Dalam mempertajam analisa, penelitian ini membandingkan keadaan yang terjadi di Sumatera Utara dalam rangka MEA, dengan Provinsi Jawa Barat. Provinsi Jawa Barat yang dianggap siap dalam menghadapi MEA terutama dari Usaha Mikro, Kecil dan Menengah (UMKM). Seperti diketahui bahwa pemberdayaan UMKM adalah salah satu kekuatan Indonesia jika mau menang dalam persaingan Masyarakat ekonomi Asean.

Penelitian mengarah pada penelitian deskriptif kualitatif yang lebih menekankan pada kebijakan politik terhadap UMKM Pemerintah Provinsi Sumatera Utara dalam Masyarakat Ekonomi ASEAN, peluang serta hambatan-hambatan yang muncul didalamnya.

\section{HASIL DAN PEMBAHASAN}

Usaha Mikro Kecil Menengah dan Koperasi (UMKM) sebagai sektor ekonomi nasional yang sangat strategis dalam pembangunan ekonomi kerakyatan, selalu menjadi isu sentral yang diperebutkan oleh politisi dalam menarik simpati massa. Para akademisi dan LSM juga banyak mendiskusikannya dalam forum-forum seminar, namun jarang sekali yang melakukan upaya riil sehingga berdampak pada peningkatan kesejahteraan UMKM. Sebagai poros kebangkitan perekonomian nasional, UMKM tenyata bukan sektor usaha yang tanpa masalah. Dalam perkembangannya, sektor ini justru menghadapi banyak masalah yang sampai saat ini belum mendapat perhatian serius untuk mengatasinya (Djabbar, dkk., 2019; Kusmanto \& Warjio, 2019).

Teknologi informasi merupakan bentuk teknologi yang digunakan untuk menciptakan, menyimpan, mengubah, dan menggunakan informasi dalam segala bentuknya. Melalui pemanfaatan teknologi informasi ini, UMKM dapat memasuki pasar global. Pemanfaatan teknologi informasi dalam menjalankan bisnis atau sering dikenal dengan istilah e-commerce bagi perusahaan kecil dapat memberikan fleksibelitas dalam produksi, memungkinkan pengiriman ke pelanggan secara lebih cepat untuk produk perangkat lunak, mengirimkan dan menerima penawaran secara cepat dan hemat, serta mendukung transaksi cepat tanpa kertas. Pemanfaatan internet memungkinkan UMKM melakukan pemasaran dengan tujuan pasar global, sehingga peluang ekspor sangat mungkin.

Penyediaan pemodalan ini juga sangat penting untuk meningkatkan kapasitas produksi suatu usaha. Oleh karenanya, dibutuhkan lembaga pemodalan yang mudah diakses oleh pelaku usaha dari berbagai skala. Terutama pelaku UMKM yang seringkali kesulitan dalam penambahan modal.

Harus diakui banyak kalangan yang belum paham dengan MEA, terutama di kalangan UKM. UKM kita selama ini banyak bergerak disektor informal di pedesaan dan cenderung belum well 
Evi Yunita Kurniaty, Kebijakan Pemerintah Provinsi Sumatera Utara untuk Usaha Mikro Kecil dan

inform. Peran pemerintah dalam mensosialisasi potensi dan peluang MEA masih perlu terus di dorong, terutama di kalangan UKM agar mampu bersaing dengan pelaku UKM negara lain.

UKM sendiri merupakan bagian penting dari perekonomian ASEAN. Sampai saat ini, 96\% dari perusahaan ASEAN adalah UKM yang terdiri 50\% sampai 95\% menggunakan tenaga kerja dalam negeri; memberikan kontribusi 30\% sampai 53\% dari Produk Domestik Bruto (PDB); dan berkontribusi 19\% sampai 31\% dari ekspor. Sementara UKM Indonesia menyumbang 99,98 persen unit usaha di Indonesia, menyumbang 57 persen PDB nasional dan lebih dari 97 persen penyerapan tenaga kerja domestik.

Masalah kesiapan dalam menghadapi MEA merupakan hal yang tidak bisa ditawar tawar lagi. Negara lain juga menghadapi kondisi hal yang sama. Sebuah survei yang dilakukan oleh Bank Pembangunan Asia dan Institut Studi Asia Tenggara (2015) menemukan bahwa kurang dari seperlima bisnis kawasan Asean yang siap menghadapi masyarakat ekonomi ASEAN.

MEA memberikan banyak peluang sekaligus tantangan bagi UKM. Sebagai kawasan perdagangan bebas, lebih dari 70 persen produk yang dibuat di ASEAN tidak akan dikenakan tarif, alias nol tarif. Ini membuat pergerakan bebas barang dan jasa yang diperkirakan dapat menurunkan harga bahan baku dan biaya produksi di Asean hingga 10-20 persen.

Kesiapan Indonesia dalam hal ini Provinsi Sumatera Utara dalam dalam Pelaksanaan Masyarakat Ekonomi ASEAN (MEA) masih terkendala pada lemahnya berbagai badang, antara lain, kesiapan Sumberdaya Manusia (khususnya UMKM), sarana dan prasarana produksi, modal usaha, infrastruktur wilayah, serta daya saing produk UMKM.

Pemberlakuan kebijakan MEA itu dapat menjadi berkah ataupun sebaliknya malah mampu sebagai ancaman. Ini sangat bergantung pada kesiapan pemerintah baik pusat maupun daerah dan masyarakat khususnya UMKM dalam menghadapinya. Namun, hingga kini Indonesia masih menghadapi masalah-masalah mendasar, khususnya dalam bidang ekonomi, politik, sosial budaya serta stabilitas keamanan.

Konsep MEA merupakan satu sistem ekonomi yang terintegrasi di dalam kawasan ASEAN. Tujuannya agar lebih maju, efisien, dan beberapa kebijakannya seperti penerapan pasar tunggal dan berbasis produksi regional, kawasan berdaya saing tinggi, kawasan dengan pertumbuhan ekonomi merata, dan terintegrasi dengan perekonomian dunia. Dalam MEA, siapa pun dari mana pun bisa hilir mudik ke Indonesia, atau sebaliknya dari Indonesia ke negara-negara Asean, untuk berjualan/membeli. Ini merupakan tantangan sekaligus peluang. Bagaimana tidak, AFTA/MEA memungkinkan mobilitas manusia makin tinggi. Keterbukaan pintu negara bagi para pendatang dari Asia dan Asean, mau tidak mau akan bersentuhan langsung dengan para pelaku usaha sejak dari bandara, di perjalanan, penginapan, pasar, tempat wisata, dan lain-lainnya. Ada begitu banyak masyarakat Indonesia yang harus berinteraksi, berkomunikasi dengan warga negara asing, mulai dari kalangan birokrat, politisi, aparat penegak hukum, sopir taksi, kondektur, tukang ojek, tukang becak, sampai dengan ibu-ibu yang menjajakan dagangan mereka di pasar.

Hingga kini ada 6 masalah utama yang masih menjadi kendala bagi Indonesia dalam meningkatkan daya saing, yakni korupsi, akses terhadap pembiayaan, inflasi, birokrasi dan pemerintahan yang tidak efisien, lemahnya dukungan Infrastruktur, serta instabilitas kebijakan. Mengutip survei WEF (World Economic Forum), Irman mengatakan, daya saing Indonesia pada tahun 2014 masih menempati urutan ke-34 di dunia. Sementara itu di kawasan ASEAN, Indonesia berada di bawah Singapura (2), Malaysia (20), Thailand (31), namun di atas Philipina (52) dan Vietnam (68).

Penilaian itu didasarkan beberapa komponen yakni birokrasi di pusat maupun daerah, kualitas infrastruktur, makroekonomi, kualitas pendidikan dan layanan dasar, serta kualitas pendidikan tinggi maupun lembaga pelatihan. Tak hanya itu, ada pula efisiensi pasar barang dan pasar tenaga kerja, pengembangan pasar finansial, kesiapan teknologi, market size, tingkat kecanggihan bisnis, serta inovasi.

Dalam rangka menggali berbagai permasalahan, kendala, serta memetakan sejauh mana kesiapan daerah khususnya provinsi Sumatera Utara baik pemerintah maupun masyarakat dalam dalam Pelaksanaan MEA maka dalam telaahan ini dilaksanakan Focus Group Discussion (FGD) yang melibatkan berbagai pihak/stakeholder yang memangku kepentingan ataupun terkait wh http://mahesainstitute.web.id/ojs2/index.php/jehss *1. mahesainstitut@gmail.com

230

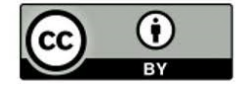

This work is licensed under a Creative Commons Attribution 4.0 
dengan MEA. Di Provinsi Sumatera Utara, FGD telah dilaksanakan di Kota Medan. Peserta terdiri dari berbagai unsur seperti Badan Perencanaan dan Pembangunan Daerah (BAPPEDA), Dinas Perhubungan, Dinas Perekonomian, Dinas Perindustrian dan Perdagangan, Dinas Koperasi, BPMKB dan UMKM (9 Asosiasi yang bergerak di berbagai bidang industri rumahan). (Laporan Akhir Telaahan Staf Ahli Menteri dalam Pelaksanaan MEA-Utamanya Mekanisme Jejaring dan Pendampingan Industri Rumahan-Studi Kasus di Provinsi Sumatera Utara dan Jawa Timur, 2016)

Pemerintah Provinsi Sumatera Utara dalam hal ini termasuk pemerintah Kabupaten/Kota telah berupaya mempersiapkan berbagai langkah baik dalam bidang kebijakan daerah, sarana dan prasarana pengembangan usaha UMKM serta kegiatan dalam peningkatan kualitas baik kualitas produk UMKM maupun Kualitas Sumberdaya Manusia (SDM), baik SDM dari pihak pemerintah maupun SDM pengelola UMKM. Perkembangan Usaha Mikro, Kecil, dan Menengah (UMKM) di Indonesia tidak terlepas dari dukungan perbankan dalam penyaluran kredit kepada UMKM. Setiap tahun kredit kepada UMKM mengalami pertumbuhan dan secara umum pertumbuhannya lebih tinggi dibanding total kredit perbankan. Kredit UMKM adalah kredit kepada debitur usaha mikro, kecil dan menengah yang memenuhi definisi dan kriteria usaha mikro, kecil dan menengah sebagaimana diatur dalam UU No. 20 Tahun 2008 Tentang UMKM. Berdasarkan UU tersebut, UMKM adalah usaha produktif yang memenuhi kriteria usaha dengan batasan tertentu kekayaan bersih dan hasil penjualan tahunan. Keberhasilan Usaha Mikro, Kecil, dan Menengah (UMKM) di Indonesia juga tidak terlepas dari dukungan dan peran pemerintah dalam mendorong penyaluran kredit kepada UMKM. Berbagai skim Kredit/pembiayaan UMKM diluncurkan oleh pemerintah dikaitkan dengan tugas dan program pembangunan ekonomi pada sektor-sektor usaha tertentu, misalnya ketahanan pangan, perternakan dan perkebunan.( Berdasarkan hasil diskusi berupa saran, masukan, evaluasi, serta paparan kondisi lapang dari para stakeholder (pemangku kebijakan, kepentingan dan berbagai pihak terkait MEA) dalam kegiatan FGD yang dilakukan Kementerian Pemberdayaan Perempuan dan Perlindungan Anak RI dan Lembaga Penelitian dan Pengabdian Kepada Masyarakat IPB)

Sampai saat ini Pemerintah Provinsi Sumatera Utara termasuk didalamnya pemerintah Kabupaten/Kota belum memiliki cetak biru yang khusus membahas dan mempersiapkan Masyarakat Ekonomi ASEAN (MEA). Berbagai usaha dan sosialisasi dalam rangka mempersiapkan MEA sebetulnya telah dilaksanakan dalam berbagai rapat, seminar maupun workshop di Provinsi Sumatera Utara namun sampai saat ini belum diwujudkan dalam cetak biru yang spesifik dalam menghadapi MEA.

Berbagai instansi/dinas di Pemerintah Provinsi Sumatera Utara pada umumnya telah memiliki komitmen serta memahami berbagai peluang dan ancaman dengan dilaksanakannya MEA. Komitmen tersebut diwujudkan dalam pengusulan program dan kegiatan dalam Anggaran Pemerintah dan Belanja Daerah (APBD) baik tingkat Provinsi maupun Kabupaten/Kota dalam rangka sosialisasi serta upaya peningkatan kualitas SDM serta kualitas produk UMKM. Kegiatan lain yang dilakukan pemerintah dalam rangka persiapan dan sosialisasi MEA adalah dengan melaksanakan berbagai kegiatan advokasi baik melalui Dewan Perwakilan Rakyat Daerah (DPRD) dalam hal ini terkait kebijakan pengusulan APBD yang melibatkan berbagai program dan kegiatan dalam persiapan MEA.

Kegiatan advokasi lainnya dilaksanakan melalui pendekatan dengan berbagai tokoh agama, tokoh masyarakat maupun tokoh daerah dengan harapan persiapan MEA tersebut didukung dan dipahami serta menjadi suatu kegiatan bersama yang membutuhkan kerjasama dan dukungan dari semua pihak. Selain itu Pemerintah Provinsi/Kab/Kota di Sumatera Utara pada umumnya telah berupaya membuat dan mempersiapkan jejaring baik dengan berbagai Lembaga Swadaya Masyarakat (LSM), Perguruan Tinggi serta berbagai perusahaan untuk memperkuat kualitas SDM, Produk UMKM maupun sektor pemasaran produk UMKM dalam rangka persiapan MEA.

Pemerintah Pemerintah Provinsi/Kab/Kota di Sumatera Utara telah memiliki prioritas dalam upaya peningkatan kapasitas daerah berupa program/kegiatan, pendampingan terhadap kegiatan UMKM melalui dinas terkait serta sektor perekonomian secara umum. Pemerintah Provinsi/Kab/Kota di Sumatera Utara juga telah mengupayakan memberikan pelayanan terhadap 
persiapan MEA baik berupa kegiatan pendampingan, pembentukan kelompok kerja, kegiatan Komunikasi Edukasi dan Informasi (KIE) serta sosialisasi melalui berbagai media komunikasi.

Pemerintah Provinsi Sumatera Utara telah melakukan berbagai upaya dalam rangka mendukung perangkat daerah (SKPD) maupun sektor usaha (UMKM) dalam rangka dalam Pelaksanaan MEA. Dukungan tersebut antara lain berupa dikeluarkannya Surat Keputusan (SK) Pemerintah Daerah dalam rangka mendukung sektor UMKM dalam pengembangan usaha sehingga diharapkan dapat membantu kesiapan UMKM dalam dalam Pelaksanaan MEA. Sosialisasi terkait berbagai kekuatan, kelemahan, peluang dan ancaman dalam peaksanaan MEA juga telah dilaksanakan dalam berbagai rapat lintas sektor dengan melibatkan UMKM di Provinsi Sumatera Utara, dengan harapan masyarakat mengetahui, memahami dan siap dalam dalam Pelaksanaan MEA, serta dalam rapat tersebut dapat digali berbagai kebijakan dan langkah strategis yang harus dilaksanakan untuk memperkuat berbagai potensi produk UMKM sehingga diharapkan siap dan mampu bersaing dengan produk luar negeri ketika nanti telah diberlakukan MEA.

Peran pemerintah Provinsi Sumatera Utara dalam skim-skim kredit UMKM ini adalah pada sisi penyediaan dana APBD untuk subsidi bunga skim kredit dimaksud, sementara dana kredit/pembiayaan seluruhnya (100\%) berasal dari bank-bank yang ditunjuk pemerintah sebagai bank pelaksana. Selain itu pemerintah berperan dalam penyiapan UMKM agar dapat dibiayai dengan skim dimaksud, menetapkan kebijakan dan prioritas usaha yang akan menerima kredit, melakukan pembinaan dan pendampingan selama masa kredit, dan memfasilitasi hubungan antara UMKM dengan pihak lain.

Pada dewasa ini skim kredit yang sangat familiar di masyarakat adalah Kredit Usaha Rakyat (KUR), yang khusus diperuntukkan bagi UMKM dengan kategori usaha layak, namun tidak mempunyai agunan yang cukup dalam rangka persyaratan perbankan. KUR adalah Kredit atau pembiayaan kepada UMKM dan Koperasi yang tidak sedang menerima Kredit atau Pembiayaan dari Perbankan dan/atau yang tidak sedang menerima Kredit

Program dari Pemerintah pada saat permohonan Kredit/Pembiayaan diajukan. Tujuan akhir diluncurkan Program KUR adalah meningkatkan perekonomian, pengentasan kemiskinan dan penyerapan tenaga kerja. KUR merupakan kredit yang diberikan oleh bank kepada UMKM dalam bentuk pemberian modal kerja dan investasi untuk usaha produktif yang feasible namun belum bankable. Tujuannya adalah tercapainya percepatan pengembangan sektor riil (terutama sektor pertanian, kehutanan, kelautan dan perikanan serta industri). Bank Indonesia (BI) mencatat penyaluran kredit Usaha Mikro Kecil dan Menengah (UMKM) masih sangat rendah di bawah 10\% sejak Januari hingga Mei 2011. Bank sentral terus mengarahkan bank untuk menggenjot kredit sektor produktif tersebut untuk mencegah ekonomi "overheating" alias kepanasan. BI membedakan kredit UMKM dan MKM karena bank saat ini tergolong masih banyak menyalurkan kredit MKM yang masih berbau konsumtif jika dibandingkan UMKM yang bersifat produktif. UMKM itu murni digunakan untuk usaha, berbeda dengan MKM yang konsumtif, BI kini mendorong bank untuk lebih menyalurkan ke UMKM.

Persoalan kurangnya modal, birokrasi yang sangat merepotkan dan ketidaktahuan akan prosedur ekspor dirasa sebagai penghambat dalam perkembangan usaha. Hal ini juga dialami oleh usaha Rendang Yugo. Dalam wawancara penelitian, usaha yang dirintis Bu Yugo sudah berjalan dari tahun 2009 dan sangat maju. Beberapa kali usahanya diliput oleh media cetak dan televisi. Memiliki dokumen yang lengkap tetapi susah untuk Bu Yugo melakukan ekspor secara formal. Untuk memenuhi pesanan dari Malaysia dan Singapura dilakukan melalui agen. Rendang Yugo sudah memiliki pelanggan tetap di Malaysia dan Singapura, bahkan rendang yugo pernah mendapat gelar makanan terlezat di dunia versi CNN. Namun hambatan dalam ekspor masih dirasa susah oleh Bu Yugo.

Lain halnya dengan usaha Fortune Shoes di Bandung. Usaha Fortune shoes sudah mampu ekspor ke negara-negara di Eropah. Bahkan menurut mereka pasar Asia Tenggara tidak menjadi pasar utama mereka. Usaha ekspor mereka sangat terbantu oleh Dinas Perdagangan dan Perindustrian Provinsi Jawa Barat, yang selalu memberikan informasi dan pendampingan kepada pengusaha dalam memanfaatkan potensi ekspor produk-produk mereka. Setiap ada perubahan 
kebijakan langsung disosialisasikan kepada pelaku usaha, sehingga pelaku usaha yang ada di Jawa Barat termotivasi dalam melakukan ekspor barang.

Penelitian juga dilakukan dengan membandingkan dengan kebijakan politik Provinsi Jawa Barat. Untuk Provinsi Jawa Barat, pemerintah sangat mendukung pelaku UMKM. Dengan diberikannya modal yang dikucurkan oleh Bank Jabar Banten (BJB). Seperti yang diutarakan oleh Dra. Hj. Elis Yatimah, MM (Kepala Bidang Kelembagaan Koperasi Dinas Koperasi dan Usaha Kecil) program kerja Gubernur Jawa Barat Ahmad Heryawan yang sangat mendukung pengembangan ekonomi kreatif melalui UMKM di Jawa Barat. Program kerja tersebut sangat berhasil dan terbukti Propinsi Jawa Barat adalah tolak ukur ekonomi kreatif di Indonesia.

Dengan ungkapan “Jawa Barat Kahiji di Asean” Dinas Koperasi dan Usaha Kecil Provinsi Jawa Barat mengambil langkah-langkah membangun SDM UMKM dan Koperasi yang berdaya saing, membangun produktivitas Koperasi dan UMKM Jawa Barat, mengambangkan Koperasi dan Usaha UMKM Jawa Barat, meningkatkan partisipasi wirausaha dalam perekonomian Jawa Barat, dan membangun wirausaha Jawa Barat yang tangguh.

\section{SIMPULAN}

Usaha Mikro Kecil Menengah dan Koperasi (UMKM) sebagai sektor ekonomi nasional yang sangat strategis dalam pembangunan ekonomi kerakyatan, selalu menjadi isu sentral yang diperebutkan oleh politisi dalam menarik simpati massa. Para akademisi dan LSM juga banyak mendiskusikannya dalam forum-forum seminar, namun jarang sekali yang melakukan upaya riil sehingga berdampak pada peningkatan kesejahteraan UMKM. Sebagai poros kebangkitan perekonomian nasional, UMKM tenyata bukan sektor usaha yang tanpa masalah. Dalam perkembangannya, sektor ini justru menghadapi banyak masalah yang sampai saat ini belum mendapat perhatian serius untuk mengatasinya. Pemerintah Provinsi Sumatera Utara telah melakukan berbagai upaya dalam rangka mendukung perangkat daerah (SKPD) maupun sektor usaha (UMKM) dalam rangka dalam Pelaksanaan MEA. Dukungan tersebut antara lain berupa dikeluarkannya Surat Keputusan (SK) Pemerintah Daerah dalam rangka mendukung sektor UMKM dalam pengembangan usaha sehingga diharapkan dapat membantu kesiapan UMKM dalam dalam Pelaksanaan MEA. Sosialisasi terkait berbagai kekuatan, kelemahan, peluang dan ancaman dalam peaksanaan MEA juga telah dilaksanakan dalam berbagai rapat lintas sektor dengan melibatkan UMKM di Provinsi Sumatera Utara, dengan harapan masyarakat mengetahui, memahami dan siap dalam dalam Pelaksanaan MEA, serta dalam rapat tersebut dapat digali berbagai kebijakan dan langkah strategis yang harus dilaksanakan untuk memperkuat berbagai potensi produk UMKM sehingga diharapkan siap dan mampu bersaing dengan produk luar negeri ketika nanti telah diberlakukan MEA.Peran pemerintah Provinsi Sumatera Utara dalam skim-skim kredit UMKM ini adalah pada sisi penyediaan dana APBD untuk subsidi bunga skim kredit dimaksud, sementara dana kredit/pembiayaan seluruhnya (100\%) berasal dari bank-bank yang ditunjuk pemerintah sebagai bank pelaksana. Selain itu pemerintah berperan dalam penyiapan UMKM agar dapat dibiayai dengan skim dimaksud, menetapkan kebijakan dan prioritas usaha yang akan menerima kredit, melakukan pembinaan dan pendampingan selama masa kredit, dan memfasilitasi hubungan antara UMKM dengan pihak lain.

\section{DAFTAR PUSTAKA}

Archaya, A. \& Johnson, A. (2007) 'Comparing Regional Institutions: An Introduction in Crafting Cooperation Regional International Institution in Comparative Perspective,, Cambridge: Cambridge University Press.

Arini, H. Badarrudin \& Kariono. (2018). Efektivitas Inkubator Bisnis dalam Pelaksanaan Pembinaan Usaha Masyarakat Kecil Menegah. Jurnal Administrasi Publik: Public Admnistration Journal. 8 (1): 1-17.

Association of Southeast ASEAN Nations. 'ASEAN Economic Community Blueprint', Jakarta: ASEAN Secretariat.

Badan Pusat Statistik Republik Indonesia,'Indikator Sosial Budaya 2003, 2006, 2009 dan 2012', Badan Pusat Statistik Republik Indonesia www.bps.go.id/tab_sub//view.php/tabel. 
Evi Yunita Kurniaty, Kebijakan Pemerintah Provinsi Sumatera Utara untuk Usaha Mikro Kecil dan

Berry A. E. Rodriguez dan Sandae H.(2001), 'Small and Medium Enterprise Dynamic in Indonesian', Bulletin of Indonesian Economic Studies, Vo.37, No 2, p. 19.

Cahyani, A., Supriatna, A., Somantri, M.S., Yuningsih, T., \& Rahman A. (2019). Analisis Sistem Administrasi di Badan UsahaMilik Desa Wibawa Mukti Desa Sekarwangi Kabupaten Sumedang. Journal of Education, Humaniora and Social Sciences (JEHSS). 2 (2): 203-212.

Djabbar, I., \& Baso, S. (2019). Pengembangan Usaha Kecil \& Menengah (UKM) Di Kabupaten Kolaka Utara. Publikauma: Jurnal Administrasi Publik Universitas Medan Area, 7(2), 116-129. doi:https://doi.org/10.31289/publika.v7i2.2974

Fawn, R, (2000) 'Explaining the Resurgence of Regionalism in World Politics', Review of International Studies, British International Studies Association.

Gilpin, R. (2001) 'Global Political Economy: Under Standing the International Economic Order', New Jersey: Princenton University Press.

Jackson, Robert \& Goerg S. (2013) 'Introduction to International Relations: Theories and Approaches'. Oxford: Oxford University Press.

Kusmanto, H. \& Warjio (2019). Pentingnya Legalitas Usaha bagi Usaha Mikro Kecil dan Menengah. JUPIIS: Jurnal Pendidikan Ilmu-ilmu Sosial, 11 (2): 320-327.

Luhulima, C.P.F. (2010), 'Dinamika Asia Tenggara Menuju 2015', Jakarta: Pustaka Pelajar bekerjasama dengan Pusat Penelitian Politik (P2P) LIPI.

Malau, M.T. (2014) 'Legal Aspect of Indonesian Goverment Regulation Against Regional Economic Liberalization: ASEAN Economic Community 2015', Journal Rechts Vinding, Vol 3 No 2, p. 163-181.

Mitsuro, H, (2002) 'Development of SMEs in the Indonesian Economy', Journal of ASIAN Economics, p. 9.

Pusat Hubungan Masyarakat Kementerian Perdagangan Republik Indonesia. 2015. Menyongsong Masyarakat Ekonomi Asean 2015. Jakarta. Kementerian Perdagangan Republik Indonesia.

Sarman, M. (2016), Laporan AKHIR Telaah Staf Ahli Kementerian dalam Pelaksanaan MEA-Utamanya Mekanisme Jejaring dan Pendampingan Industri Rumahan-Studi Kasus di Provinsi Sumatera Utara dan Jawa Timur, Jakarta. Kementerian Pemberdayaan Perempuan dan Perlindungan Anak Republik Indonesia dan Lembaga Penelitian dan Pengabdian Masyarakat (LPPM) IPB.

Sudana, R.S. (2014),'Peranan Kebijakan Pemerintah Indonesia dalam Persiapan Menyongsong ASEAN Economic Community', e-journal dalam http://www.conftool.com/sudana, diakses 14 Maret 2017.

Sulistia, D., \& Suparman, N. (2019). Peranan Pembinaan Dinas Koperasi Dan Usaha Kecil Jawa Barat Dalam Memajukan Perkoperasian Di Daerah. Publikauma : Jurnal Administrasi Publik Universitas Medan Area, 7(2), 58-70. doi:https://doi.org/10.31289/publika.v7i2.2818

Suryohadiprojo, S. (2014), 'Mengorbarkan Kembali Api Pancasila', Jakarta: Penerbit Kompas.

Wahyudin, D. (2014) 'Peluang atau Tantangan Indonesia menuju Asean Economic Community (AEC) 2015, Prociding.

Winarno, B. (2011), Isu-Isu Global Kontemporer. Jakarta: PT. Buku Seru.

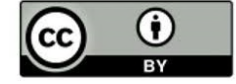

This work is licensed under a Creative Commons Attribution 4.0 